Georgia State University

ScholarWorks @ Georgia State University

Middle and Secondary Education Faculty

Publications

Department of Middle and Secondary Education

2019

\title{
Black Girls Speak STEM: Counterstories of Informal and Formal Learning Experiences
}

Natalie S. King

Georgia State University

Rose M. Pringle

University of Florida

Follow this and additional works at: https://scholarworks.gsu.edu/mse_facpub

Part of the Curriculum and Instruction Commons, and the Junior High, Intermediate, Middle School Education and Teaching Commons

\section{Recommended Citation}

King, Natalie S. and Pringle, Rose M., "Black Girls Speak STEM: Counterstories of Informal and Formal Learning Experiences" (2019). Middle and Secondary Education Faculty Publications. 144.

doi: https://doi.org/10.1002/tea.21513

This Article is brought to you for free and open access by the Department of Middle and Secondary Education at ScholarWorks @ Georgia State University. It has been accepted for inclusion in Middle and Secondary Education Faculty Publications by an authorized administrator of ScholarWorks @ Georgia State University. For more information, please contact scholarworks@gsu.edu. 


\title{
Black Girls Speak STEM: Counterstories of Informal and Formal Learning Experiences
}

\author{
Natalie S. King \\ Georgia State University \\ Rose M. Pringle \\ University of Florida
}

\begin{abstract}
This study presents the interpretations and perceptions of Black girls who participated in I AM STEM a community-based informal science, technology, engineering, and mathematics (STEM) program. Using narrative inquiry, participants generated detailed accounts of their informal and formal STEM learning experiences. Critical race methodology informed this research to portray the dynamic and complex experiences of girls of color, whose stories have historically been silenced and misrepresented. The data sources for this qualitative study included individual interviews, student reflection journals, samples of student work, and researcher memos, which were triangulated to produce six robust counterstories. Excerpts of the counterstories are presented in this article. The major findings of this research revealed that I AM STEM ignited an interest in STEM learning through field trips and direct engagement in scientific phenomena that allowed the girls to become agentic in continuing their engagement in STEM activities throughout the year. This call to awaken the voices of Black girls to speak casts light on their experiences and challenges as STEM learners - from their perspectives. The findings confirm that when credence and counterspaces are given to Black girls, they are poised to reveal their luster toward STEM learning. This study provided a space for Black girls to reflect on their STEM learning experiences, formulate new understandings, and make connections between the informal and formal learning environments within the context of their everyday lives, thus offering a more holistic approach to STEM learning that occurs across settings and over a lifetime.
\end{abstract}

Keywords: Black girls; informal STEM learning; middle grades; counterstories; counterspaces; critical race feminism; equity 


\section{Introduction}

A typical day in science class goes something like this: First we get started and my teacher introduces our homework for the week. So we do homework from Monday through Friday, and then you can turn it in whenever you want. Well not past Friday, obviously. So, the teacher introduces our homework, tells us what our homework's about. Then if we've taken a mini-assessment, we go over the mini-assessment. Everybody sees what they've got, the class gets mostly B's... but I get A's. Everybody's jealous. I like that. They're very jealous of me. So in science class we take notes all day. It's really boring. We take notes, and watch the school news to see what our snack is. (Amaria, $5^{\text {th }}$ grade)

Amaria's sentiments regarding the mundane nature of her science class is one that occurs too often in public schools serving populations of students already underrepresented in science. Amaria's vignette is supported by researchers Sreyashi Jhumki Basu and Angela Calabrese Barton (2007) and Felicia Moore Mensah (2013), that many students, particularly those of color attending urban schools in economicallychallenged communities experience science as a subject that is boring, confusing, and frustrating. This rhetoric of science being disconnected from the interests and experiences of children of color is commonplace, with a paucity of research being conducted on how to catalyze, harness, and sustain these interests. Amaria reported that she excelled academically in science class as a fifth grade student, but how can her interest and participation be nurtured as she matriculates through middle and high school?

With the existing and ever increasing diversity among US citizens, it is essential that all students are afforded equitable access to high-quality education for an opportunity to become productive citizens and lifelong learners (Horsford, 2011; Juárez \& Hayes, 2010, 2012; Ladson-Billings, 2013).

Furthermore, diversification of individuals within science, technology, engineering and mathematics (STEM) has the potential to contribute new insights and interpretations that can further the advancement of these fields (Meador, 2018). Even though higher percentages of all US students are reaching proficiency levels in mathematics and science, disaggregation of the data reveal that progress is slow and large disparities still persist across gender, racial, and income lines (Corbett, Hill, \& St. Rose, 2008; National Science Foundation [NSF], 2017). The impetus to increase the participation of diverse populations in the STEM disciplines has centered around maintaining U.S. global competitiveness and economic prosperity which is a self-serving initiative that lacks sincere moral concern or commitment to the well-being of children of color (King, 2017; Martin, 2009). The low participation of women and minorities in STEM careers still remains a growing concern prompting a movement toward broadening participation efforts (George, Neal, Van Horne, \& Malcolm, 2001; Hernandez-Gantes \& Fletcher, 2013; NSF, 2017). Notably, Black girls have consistently scored below basic proficiency levels in science when compared to their White counterparts (Hanson, 2009; Aud, Fox, \& KewalRamani, 2010).

Research supports that Black girls begin losing interest in science during the middle school years, and choose not to take advanced science courses in high school and college (Pringle, Brkich, Adams, WestOlatunji, \& Archer Banks, 2012; Corbett et al., 2008; Hanson, 2009). There is a demonstrated need to increase the participation of Black girls in science, but an even greater need exists to paint a systemic portrait that portrays the science talents and proficiency of Black women and girls. Ireland et al. (2018) posit that the unique experiences of Black women and girls are hidden in aggregate results, and their intersectional experiences are often overlooked. A recent special issue that explored how learners develop their disciplinary identities and why they engage within and across settings, revealed the need to design learning environments that support youth who learn along racialized, gendered, and classinfluenced pathways (Bell, Van Horne, \& Cheng, 2017). This is particularly essential and relevant in this nation's sociopolitical context because learners negotiate their identity development across 
educational contexts (Bell et al., 2017). Therefore, not only should research highlight the plight of Black girls, but their multidimensional identities must also be acknowledged and valued.

In this study, Black girls were afforded with opportunities to participate in STEM-related activities and provided a platform to share their successes and cast light on their challenges as learners. Specifically, the purpose of this research was to elicit the voices of Black girls who participated in a community-based informal STEM program-I AM STEM, to understand their STEM learning experiences in informal and formal contexts, and document how the girls translated their informal learning experiences into practice within their formal schools. The following research questions guided the study:

1. How do Black girls access, engage in, and respond to STEM learning experiences in I AM STEM a community-based program?

2. In what ways do Black girls translate learning from I AM STEM into practice in their formal schools?

3. What roles (if any) do Black girls perceive that race, gender, and/or class play on their STEM learning experiences?

\section{Conceptual Framework}

\section{Critical Race Feminism and Counterspaces}

In this study, critical race feminism (CRF) was used as a lens to expose racial and gender essentialism as Black girls navigated between formal and informal STEM learning spaces. CRF focuses on the lives of those who face multiple discrimination on the basis of race, gender, and class, and reveals how these factors interact within a system of White male patriarchy and racist oppression (Wing, 1997). In giving credence, Wing (1997) further discusses that women of color are not White women with pigmented skin as a secondary characteristic, but rather individuals who experience multiple forms of discrimination due to their race, gender, and class in an American society permeated by White supremacy (Wing, 1997). In this study, race, class, and gender are social phenomena within larger sociohistorical and political structures. Race, in particular, is a visible or physical appearance serving as a marker of difference, and is intrinsically connected to power relations and hierarchy (Bonilla-Silva, 1999; Parsons, 2014). The participants self-identified as Black; therefore this research does not delve into specifics regarding ethnicities or cultural heritages. In this article, the terms "Black" and "White" are capitalized and used to signify racial identity (American Psychological Association [APA], 2010). CRF as a multidisciplinary approach emphasizes both theory and practice, where dialogue around issues for women of color is supplemented with praxis by acting on micro and macro levels to improve the plight of Black women and girls. This research answers a call "to alleviate the knowledge desert that exists around the lives and experiences of Black women and girls" who have fallen between the cracks of reports on Black men and White women (Crenshaw \& Allen, 2014, p. 6) by exploring the multiple identities and experiences of girls of color, and surfacing (from their perspectives), the complex intersections of race, gender, and class in STEM learning spaces.

To effectively surface issues of concern for Black girls and women, we indicated a need for a counterspace to provide a safe and brave space conducive for rich dialogue. For this study, we embraced Solórzano, Ceja, and Yosso's (2000) definition of counterspaces as "sites where deficit notions of people of color can be challenged and where a positive climate can be established and maintained" ( $p$. 70). Case and Hunter (2012) purport that counterspaces are proactive attempts to ensure that the patterns 
of marginalization prevalent in the larger societal context are not reproduced in these spaces. Thus, the functional mechanism of counterspaces is to challenge deficit notions that lead to self-enhancement, and ultimately, adaptive responses.

Counterspaces facilitate and promote the psychological wellbeing of individuals who have been marginalized or experienced oppression (Case \& Hunter, 2012). Howard-Hamilton (2003) encourages the use of counterspaces as a conceptual framework for Black girls and women because they provide shelter from the "daily torrent of microaggressions" (p. 23) and can be fostered through positive support systems, which include family, friends, community members, and organizations. Scholars have recently explored the importance of having counterspaces within STEM education (Ashford, Wilson, King, \& Nyachae, 2017; Lane, 2016; Ong, Smith, \& Ko, 2018; Smith, 2016; Wilson \& King, 2016). Ong et al. (2018), explored the functionality of counterspaces for women of color in STEM higher education and reified the need to be deliberate in the creation of counterspaces at the center of STEM, rather than women of color being forced to create those spaces at the margins. Their findings also indicate that counterspaces are not limited to physical settings but can also be conceptual and idealogical in nature. Including more stakeholders in the fight to address bias, exclusion, and marginalization within STEM can begin the process of centering STEM counterspaces.

In this study, the informal STEM program - I AM STEM served as an academic and social space for Black girls to problematize deficit-notions, establish and maintain relationships, and validate each other's experiences as important knowledge (Solórzano et al., 2000; Solórzano \& Villalpando, 1998). The program was housed at a local community center with a specially-designed curriculum for the girls to fully engage in experiential learning and lessons that directly connected science with their interests, lived experiences, and local concerns. The girls developed relationships with their peers, teachers, community members, and other role models/mentors within the STEM disciplines. These interrelationships between and among participants, aggregated with a curriculum that focused on issues of social and environmental justice within their communities, were structures in place for the girls to develop critical consciousness.

Furthermore, the girls' engagement in this study co-constructing knowledge about their STEM learning experiences served as an additional, and likely more complex, layer of counterspaces because the dialogue continued beyond the physical space of the community-based informal STEM program. Notably, the girls made sense of how their STEM learning experiences across settings informed the ways in which they perceived and defined themselves as STEM learners through their interactions with researchers. Figure 1 visually depicts how the conceptual framework was used as a lens to inform the study with special emphasis on the enclosed area.

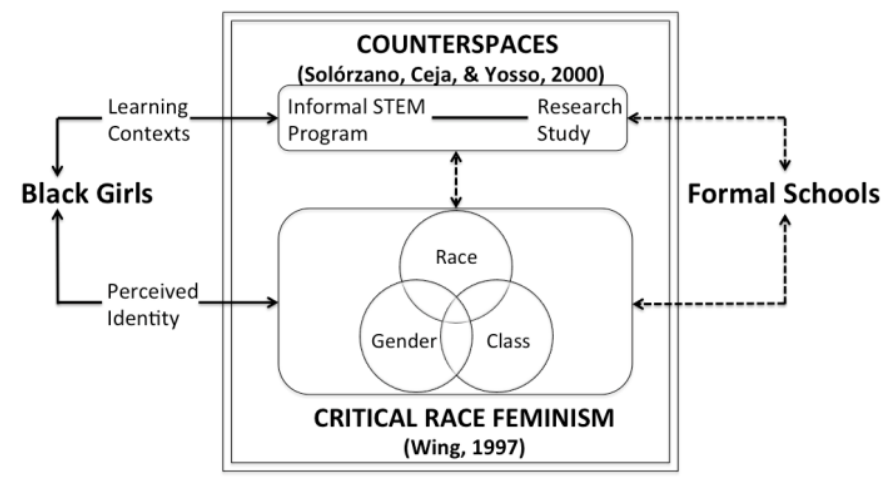

FIGURE 1 Multidimensionality of Black Girls' STEM Learning: A Conceptual Framework 
Many scholars have examined Black girls in formal learning spaces (Buck, Akerson, Quigley, \& Weiland, 2014; Evans-Winters, 2005) and how children of color respond to informal STEM learning experiences (Falk et al., 2016; Jones, 1997), yet very few studies have specifically focused on how Black girls navigate between informal and formal learning spaces. This study is unique in that the girls engaged in a STEM program within their community, and were invited into a research space where their voices and lived experiences were included and reified as important knowledge. The focus of this study was not on formal schools, but rather on how the girls translated their learning and experiences from the informal STEM program into the formal space. Bidirectional dashed arrows are used to represent this relationship because the role of formal schools on the development of girls as STEM learners cannot be ignored. Therefore, this study did not focus on identity formation, but rather on how the girls' STEM learning experiences were impacted by the complex interactions and intersections of their perceived multidimensional identities within and across contexts and spaces. By exploring the intersections of learning contexts and perceived identities, our research provides a more comprehensive approach to explore the STEM learning experiences of Black girls.

Due to the nature of this study, the researchers were conscientious regarding naming ourselves and our participants in efforts to promote equity in science education and respect for all members. In a JRST Editorial, critical scholars, Rivera Maulucci and Mensah (2015) shared their own personal stories and discussed the importance of naming ourselves and others in which identifications intersect with issues of power, privilege, and social justice. They warn against "othering" by using terminology such as "underrepresented", "marginalized", or "underserved" to describe our research participants who identify with groups traditionally not represented in science - be it female, Black or Latinx, or individuals with disabilities. In this study, research participants defined their own positionality self-identifying as Black girls.

In our quest as researchers to explore the successes and challenges of Black girls' experiences in STEM learning spaces, we had to reposition ourselves as learners to unearth critical insights. Therefore, the girls were invited into the research process and intentionally positioned as co-constructors of knowledge. Howard (2001) emphasized the importance of foregrounding students' viewpoints and interpretations of their schooling experiences in our research to further discussions about reform efforts. Students' perspectives provide unique insights into the teaching and learning process, particularly for students who have been marginalized in formal schools. This study provides a platform and space for Black girls to share their stories, moving them from research subjects to co-constructors of knowledge.

\section{Subjectivity Statements}

"As long as we are human, the first filter through which we look will be the one constructed by the events of our individual lives" (Grillo \& Wildman, 1991, p. 409). As qualitative researchers examining the experiences of Black girls in STEM learning spaces, we have surfaced our own biases, experiences, and subjectivities to provide a level of transparency to the readers. Our personal histories, cultural worldviews, and professional experiences color our lens and decisions for how we approached this study. Due to the interactional and constructional nature of the research process, we name ourselves and share life experiences that have shaped our commitment to this work. Evans-Winters and Esposito (2010) discuss the need for more women scholars of color to directly confront the social and educational needs of girls of color, documenting the unique challenges they encounter due to their raced, classed, and gendered status. They purport that the stressors that Black girls may face in their homes, 
communities, or schools can be buffered by exposure to successful Black women and support systems to help them cope and persist.

\section{Author 1 - Natalie S. King}

I position myself as a Black middle-class woman, scholar, and science educator. As a woman of color who grew up in the American public school system, I have experienced the ways in which the intersectionality of my race, gender, and class has played out in unique and complex ways during my educational journey. I am committed to exploring the science learning experiences of Black girls in the middle grades because not only does research support that they begin losing interest during this time, but I personally began to lose interest in science while in middle school. Many of my science classes consisted of reading science textbooks and completing worksheets. The only memory I have being actively engaged in science during elementary school was when my fifth grade teacher facilitated a dissection of owl pellets as we learned about the eating habits of birds. I was finally provided with an opportunity to authentically engage in science beyond just the pages of a textbook or worksheet. Upon entering middle school, I became disconnected from science and did not reconnect until my sophomore year of high school when I started the chemistry sequence in the International Baccalaureate (IB) program. My teacher included experiments and devoted sufficient time for scientific investigations, however, the environment was competitive and the students who really excelled excluded me from their circle. The class size was small, and I vividly remember my heart pounding excessively and dropping to the tip of my toes whenever grades were posted on the board after a major test or laboratory report. It always seemed so high-stakes with an emphasis on passing the IB Chemistry Higher Level Exam. I earned great grades all three years, but still did not identify with science. It was not until my freshman year of college in my Chemistry I course with Dr. Harrison that I experienced a major shift. One day, I mustered up enough courage to visit Dr. Harrison's office hours and he stated that what separated me from most college students was that on a Friday afternoon when others were concerned about what party they will be attending, I was interested in mastering coffee cup calorimetry. On that day, a scientist recognized the scientist in me. Dr. Harrison validated my abilities and valued my strengths as a science learner. Needless to say, I received an " $A$ " in this course, but the impact of his simple statement resonated deeply. With my newfound confidence, I sat on the front row of lecture, never missed a day of class, and even began tutoring my peers in chemistry. In a class of hundreds of college students, I felt secure in my ability to perform well in science with my focus shifting from competing to be on the right side of the bell curve, to embracing opportunities to demonstrate my mastery by teaching others. Upon graduating with my bachelor's degree, I became a high school science teacher and realized that many of the Black girls in my classes internalized feelings of inadequacy, and were unconfident in their abilities to excel in science. This is consistent with Hanson's (2009) premise that Black girls begin losing interest in science during the middle school years, and choose not to pursue the hard sciences in high school and college. Therefore, as a science educator, I have taken critical action to advocate for access and equity of STEM learning experiences for children of color, particularly Black girls, through the development of community-based programs. I am the founder and executive director of I AM STEM - the research context of this article. My commitment to creating and implementing community-based informal STEM programs and providing a platform for Black girls to share their stories to inform practice, theory, and research is how I have joined the struggle for social justice to "write and right the truths of history" (Zamudio, Russell. Rios, \& Bridgeman, 2011, p. 7). My passion, scholarship, and activism was birthed from my desire to create spaces for Black girls to have positive experiences in science, where they are valued and validated, and can position themselves as adept science learners. 


\section{Author 2 - Rose M. Pringle}

I began my life-long career in education teaching science at an all girls' high school in the Caribbean. At that time in my country of birth, the examinations certifying completing high school and positioning for postsecondary education were administered by external examination organizations such as Cambridge Assessment International Education and the Caribbean Examination Council. The girls in my classes were exceptional in their science and mathematics achievements and went on to make stellar contributions in STEM-related fields post graduation. Therefore, as a Black woman immigrant entering into academia in the U.S., I was firm in my conviction that girls of African descent can excel in science.

Now as a science educator at a research intensive university, my research interests have revolved around issues in science teacher education including teacher learning and effective science-specific classroom practices with a focus on the underrepresentation of populations of learners in science, specifically Black girls. I have therefore spent countless hours in science classrooms observing, modeling best teaching practices, and engaging teachers in a range of professional development programs. In these spaces, I have witnessed the inequities that exist within and across public schools and have conducted studies exploring the positionality of girls in science and mathematics. The findings were upsetting, yet not surprising. One such finding points to the notion that although teachers were well-intentioned, their perceptions and lack of awareness of their roles in advancing Black girls as science and mathematics learners, in many ways, limited the opportunities the girls were afforded (West-Olatunji et al., 2010). As a parent of a Black girl, my daughter studied electrical engineering and would have abandoned her career aspirations prior to graduation had it not been for the strong family support that we provided. The support was mainly psychological as we struggled with the messages she received regarding the extent to which she was capable of completing the degree in electrical engineering.

I therefore came to the summer program and this study with a belief that STEM education for girls of African descent should include attention to their cultural identities and background experiences, along with the enactment of a curriculum that includes sociopsychological support. My involvement in I AM STEM extends beyond the role of participant observer in the research process. As a member of the community, I have observed the nature of the enactment of the program activities and the interactions between teachers and the students. In addition, I have worked with one of the middle school science teachers in professional development program through the university, and have also enrolled my grandson to participate in the program. I am vested in my work as a science educator and hope that my scholarship will, in deliberate ways, raise consciousness, inform practices, and result in improved academic achievement for populations who have been underserved in science, notably Black girls.

\section{State of Black Girls in Science}

Researchers contend that student identities, and teachers' responses to these identities, are shaped by gender, race, and class relations (Brickhouse Lowery, \& Schultz, 2000). According to Catsambis (1995), even though girls are beginning to achieve in science at equal or higher rates than their male counterparts, girls of all ethnic groups have fewer science learning experiences and more negative attitudes toward science. Furthermore, Barton (2007) reported that during the middle grades, girls are already deciding whether or not they want to pursue the STEM trajectory, making it a critical time for them to receive positive science learning experiences. 
Focusing on Black girls specifically, literature indicates that even though they show some interest in science, Black girls often do not feel welcomed and experience racism and sexism in their science classes (Malcolm, Hall, \& Brown, 1976; Rayman \& Brett, 1995; Vining-Brown, 1994). According to Hanson (2009), Black girls are aware of biases and inequities within the educational system due to their race and gender, and perceive that the color of their skin has played a more critical role than gender on their unequal footing in science than their gender. Other research supports that Black girls who are high-achieving are typically disadvantaged by their teachers and school counselors who underestimate their potential and do not have high expectations for their academic success (Brickhouse et al., 2000; Brickhouse \& Potter, 2001; Next Generation Science Standards [NGSS] Lead States, 2013).

A recent report indicates that Black girls are often stereotyped before they even enter into a school building, which impacts their self-esteem and self-perceptions (Smith-Evans, George, Graves, Kaufmann, \& Frohlich, 2014). These stereotypical images attached to Black girls form the reference point from which they are afforded learning experiences, and expectations are lowered compared to their White counterparts (Nasir, Snyder, Shah, \& Ross, 2012; Pringle, et al., 2012). This is further compounded because oftentimes school norms are not congruent with the cultural practices of Black girls, forcing them to either conform to middle class notions of how girls should behave, or get disciplined for defying those expectations (Parsons, 2008; Smith-Evans et al., 2014). Morris (2007) reported that there is a tainted perception of Black femininity in middle-class schools, and Black girls are perceived as inadequately feminine because they often do not conform to that particular model of womanhood. This mismatch between cultural practices and school norms reifies why Black girls experience stereotype threat, and marginalization within their science classes (Nasir et al., 2012; Steele, 1997).

Discourses of belongingness in school science identify White middle class students as scientific talent, which are often perpetuated by teachers, administrators, and their peers (Olitsy, Flohr, Gardner, \& Billups, 2010). Due to the lack of critical mass of Black girls pursuing the STEM disciplines, they consistently experience isolation, alienation and tokenism in STEM classrooms (Lane, 2016). They also, often experience difficulty in building a community and support system to persist in hostile and competitive academic spaces (Strayhorn, 2012). Black girls are trailing behind their peers in science and mathematics narrowing their career options and potential quality of life as adults (Pringle, et al., 2012). To increase the participation of Black women in STEM fields, the culture of science and science teaching must be transformed to one that values girls, students of color, and those who come from low socioeconomic households (Aud, Fox, \& Kewal Ramani, 2010; George et al., 2001; Hanson, 2009; Hernandez-Gantes \& Fletcher, 2013).

In a review of the literature, relatively few studies specifically explored Black girls' participation in formal and informal science learning spaces (Ashford, Wilson, King, \& Nyachae, 2017). One study described an enrichment program that provided Black high school girls with afterschool tutoring, inquiry-based activities, role models, and mentoring (Ferreira \& Patterson, 2011). The researchers noted the positive impact of the program on the girls' achievement and attitudes toward science. Furthermore, as students became more familiar with the lives of Black women scientists, they began considering the possibility of themselves pursuing science-related careers (Ferreira \& Patterson, 2011). Another study explored Black girls in the first grade attending a single-gender school engaged in scientific practices through contextualized and decontextualized activities (Buck et al., 2014). Findings from this study revealed that there was an increase in the percentage of girls demonstrating informed levels of understanding about observation, inference, and empirical evidence (Buck et al., 2014). An out-ofschool program, Digital Youth Divas, used project-based design challenges through virtual and face-toface mechanisms to engage middle school girls of color in computational activities (Pinkard, Erete, 
Martin, \& McKinney de Royston, 2017). The blended learning program integrated programming and electronics through interactive narratives to spark the girls' interests in STEM and mediate their sense of STEM agency. A study that was conducted at the postsecondary level explored the development of a course at Spelman College, a Historically Black College and University (HBCU) for Black women (Pai et al., 2010). This course infused rigorous coursework that was student-centered with a case study approach and small group discussions. These instructional strategies were highly effective for Black women and increased their interests and science content knowledge significantly. A recent study explored the importance of teachers' involvement in community-based informal spaces to support the STEM learning experiences of Black girls (King, 2017). Findings revealed that teachers were instrumental in forging authentic relationships with parents, encouraged Black girls to think critically and creatively during out-of-school time, and built a community of learners that promoted academic success and engagement.

A synthesis of research examining the intersectional experiences of Black women and girls in STEM education revealed that Black girls have distinct experiences due to their social identities, psychological processes, and educational outcomes (Ireland et al., 2018). This review discovered that many studies have not addressed the key psychological processes associated with identity nor the simultaneous racialized and gendered experiences in STEM educational settings. In accordance with the summation of the review, this study seeks to cast light on the racialized and gendered experiences best told through the girls' stories.

\section{Access to Informal Science Education through Informal STEM Programs}

There is a growing need to make science learning accessible to more populations of students by providing a safe space for them to explore their interests in STEM, in non-threatening and low-stakes environments. The National Research Council (2011) reported that instructional time for science is reduced in schools as a result of federal policies emphasizing and incentivizing mathematics and literacy. To compensate for this reduction in science learning opportunities, studies have shown that engaging in informal science learning is one approach to engage Black girls in science and mathematics because they often experience more academic success in these out-of-school settings (Barton, 2007; Ladson-Billings \& Tate IV, 1995; Shujaa, 1994). Students' sustained interest in science is typically cultivated in non-traditional venues such as afterschool and summer science programs (Basu \& Barton, 2007). Banks et al. (2007), in giving credence to informal learning, noted that most of the learning that occurs across the life span takes place in informal settings. Thus, learning science in informal environments can be an effective approach to increasing learning opportunities and addressing educational inequities, thereby broadening the participation of individuals engaged in STEM learning (Basu \& Barton, 2007; Falk et al., 2016; Feinstein \& Meshoulam, 2014; Jones, 1997). Informal science learning is broadly defined, and includes any science learning that occurs outside of school ranging from visiting museums, playing outside, participating in summer camps, watching television, reading books, browsing the internet, to even raising pets at home (Dierking, Falk, Rennie, Anderson, \& Ellenbogen, 2003; Falk 1999, 2001, 2005; Falk \& Dierking, 2002; Feder, Shouse, Lewenstein, \& Bell, 2009; Rennie, 2007; Tal, 2012). For this study, we employ Dierking and colleagues' (2003) definition of informal science education as "science learning that occurs outside the traditional, formal, schooling realm" (p. 108). Furthermore, our work is guided by Feder et al.' (2009) six overall goals and practices of informal science learning: (1) developing interest in science, (2) understanding science knowledge (3) engaging in scientific reasoning, (4) reflecting on science, (5) engaging in scientific practices, and (6) identifying with the scientific enterprise. 
Recent research related to informal science, informal STEM, and free-choice learning is concerned with how to build bridges within communities, across content areas, and between research and practice to create STEM learning ecosystems (Falk et al., 2016). STEM learning ecosystems harness the unique contributions of different entities within a community to deliver STEM learning that is relevant, responsive, and appropriate for all students (Falk et al., 2016; Traphagen \& Traill, 2014). One such example is the Synergies research-practice partnership in the Parkrose community in Portland, Oregon. In this partnership, researchers developed a Parkrose STEM Education Plan and customized learning opportunities that embraced students' cultures, families, and community. National reform efforts and funding initiatives have also focused on ways to broaden and deepen access and participation of groups who have historically been underrepresented in the STEM disciplines (NGSS Lead States, 2013; National Research Council, 2015; National Science Foundation, National Center for Science and Engineering Statistics, 2017). As a community-based informal STEM program, our goal is to provide access to high-quality STEM learning experiences through community collaborations and partnerships. Community-based informal STEM programs are designed to broaden the participation of individuals who have been traditionally underrepresented in STEM fields by strategically operating within communities of color, particularly communities that have experienced economic challenges. Through partnerships and sharing of resources, programs can be made accessible and affordable to families in the community. Community-based informal STEM programs, like the one described in this article, are sustained by communities converging their interests to support students' engagement in and exposure to the STEM disciplines (King, 2017).

While out-of-school science experiences have the potential to stimulate students' interest in science and positively impact their academic achievement, further research is still needed to unpack how to foster meaningful STEM learning experiences for men and women of color in the STEM workforce (National Research Council, 2012, 2015). Philip and Azevedo (2017) purport that contexts for everyday science learning are not neutral, and name three discourses that can be used to uncover assumptions about equity - (1) discourses that emphasize increased student achievement, (2) discourses that problematize the privileged forms of science, and (3) discourses that identify science in justice movements. Welldocumented research reveals that access to informal science learning environments has largely been skewed toward dominant cultural groups (i.e, White and Asian students), providing enrichment to less diverse and more privileged populations due to the location and costs of these programs (Feinstein $\&$ Meshoulam, 2014; Jones, 1997; National Research Council, 2015). However, what is missing from the literature is how to best foster more equitable science learning experiences for diverse groups of students that attend to their cultures, while informing basic theory about learning in informal settings. McCreedy and Dierking (2013) purport that "despite significant investment, the field knows very little about the possible long-term impacts and contributions informal STEM programs can make in young women's lives, both generally, and in the area of STEM specifically" (p. 5). Listening to the experiences of Black girls and observing them in informal contexts can provide insights on how to effectively engage Black girls in science, and foster their sustained interest and participation in STEM careers.

\section{Methodology}

This qualitative study embraced a social constructionist epistemological stance, which argues that the way in which we understand the world is historically, culturally, and socially defined (Burr, 2015; Crotty, 1998; Weinberg, 2014). An important premise of social constructionism is that knowledge is not objective, but rather constructed through the daily interactions between people. Hence, it cannot be assumed that one particular way of knowing is more advanced or nearer to the truth than another (Burr, 
2015; Crotty, 1998). Social constructionism adds the critical element of human-to-human interaction across social and cultural contexts (Weinberg, 2014), which was critical in the co-construction of the girls' counterstories. In alignment with the conceptual framework of critical race feminism (Wing, 1997) and counterspaces (Solórzano et al., 2000), critical race methodology (Solórzano and Yosso, 2002b) was the methodological framework that informed this research study. Critical race methodology exposes and challenges deficit-informed research paradigms that have historically silenced and misrepresented the experiences of people of color. This methodology embraces five themes to understand the experiences of students of color and how they respond to the educational system:

1. The intercentricity of race and racialized oppression

2. The challenge of dominant ideology of White privilege, race neutrality, and meritocracy

3. The commitment to social justice toward empowerment of oppressed minority groups and elimination of racism, sexism, and poverty

4. The centrality of experiential knowledge and its legitimacy and appropriateness in understanding the lived experiences of people of color

5. The transdisciplinary perspective to understand how racism, sexism, and classism impact people of color

Racism ignores the complexities and cultural richness of minority groups and replaces it with master narratives that have been maintained by White privilege. Critical race methodology encourages those who have been oppressed to share their stories and listen to others as a form of empowerment and realization that they are not isolated in their marginality. Stories of lived experiences told by the participants allow them to reclaim authorship of their own lives (Giroux, 1988; Howard, 2001). Critical race methodology is unconventional and allows space for creativity in the methods employed to communicate the experiences of students of color (Solórzano \& Yosso, 2002a). This approach embraces the combination of qualitative data sources in the construction of rich counterstories. Counterstories is a method of sharing the stories of those who have been oppressed or marginalized by society in order to strengthen cultural traditions and expose and challenge the master narratives (Solórzano \& Yosso, 2002a). According to Solórzano and Yosso (2002b), counterstories serve the four following purposes: (1) building community by those who have been marginalized by society; (2) providing context to recognize and change established belief systems; (3) opening new possibilities for those who society has marginalized and isolated; and (4) constructing a more meaningful world by combining stories with reality. Counterstories are personal and not meant to define universal experiences of people of color (Zamudio et al., 2011). Therefore, composite characters were not created in order to illuminate the uniqueness of each girl's experience. This is consistent with critical race methodology that relies on the premise that there is no single, monolithic nonwhite voice, but people of color speak from their personal and lived experiences (Delgado, 1990). Critical Race Feminism (Wing, 1997) and counterspaces (Solórzano et al., 2000) as a conceptual framework embrace non-traditional writing genres in the form of counterstories in order to challenge traditional methodology. The purpose of this study is not to be generalizable, but rather to portray the unique science talents and proficiency of Black girls. Hence, counterstories as a research method provided a platform for Black girls to share their stories and voice their realities.

The researchers, as community members and participant observers, developed a relationship with the girls and provided a safe space conducive for them to freely express their lived experiences and multidimensional identities. It was in this space where rich dialogue occurred between the researchers and the girls, ultimately leading to the development of six counterstories highlighting their STEM 
learning experiences. As science educators, we diligently listened to the girls to co-construct their counterstories with authenticity - stories of pride that retained power over their language and voices.

\section{Research Context and Participants}

The context of this study is a community-based informal STEM program - I AM STEM, which was housed on the campus of a community center in the southeastern region of the U.S. The location of the STEM program was strategically selected to meet the specific needs of the community. According to zipatlas.com (2018), the zip code where the center is located has troubling statistics related to educational and income disparities $-30 \%$ of the population over 25 years old do not hold a high school diploma or its equivalency compared to the national average of $19.6 \%$. The majority of residents have unskilled service-oriented jobs with $22 \%$ of the households earning less than $\$ 10,000$ each year which is more than double the state and national average of about $10 \%$. Furthermore, the property value for $45 \%$ of the homes is less than $\$ 50,000$ (national average is 10\%) with $93 \%$ of homes valuing less than $\$ 100,000$ (national average is $41 \%$ ). Situated in this community, the program seeks to provide access to STEM for social justice and hopes that exposure will break the cycle of intergenerational poverty. This commitment to social justice toward the empowerment of underserved groups to eliminate poverty is in direct alignment with critical race methodology.

I AM STEM Camp is a summer program that offers a comprehensive STEM curriculum for K12 children during the summer, with goals of improving their interests and engagement in the STEM disciplines. I AM STEM prepares students to become responsible and scientifically literate citizens and aims to prevent summer learning loss which occurs when students are not engaged in formal instruction or practicing academic skills learned during the previous school year (Cooper, 2003; Maríñez-Lora \& Quintana, 2010). Since its inception, the program has served over 750 students by providing STEM enrichment, mentoring, tutoring, and character development for the overall wellbeing of the participants. The program is advertised through a local newspaper, and flyers are distributed in schools, churches, and community centers. There is no selection process and I AM STEM is open to parents who are seeking an academic enrichment program for their children. Many of the summer programs offered in this community are through the city and focus on sports and outdoor play. Other academically focused programs are located on the other side of town, and are often too expensive for many of the families. Therefore, parents enroll their children in I AM STEM due to its affordability, convenient location, and balance between fun activities and academics. In addition, this community-based program is operated in partnership with local organizations, businesses, and university students and faculty, which exposes children to colleges, careers, and other informal science institutions.

I AM STEM aligns with the six strands of informal science learning as presented by Feder et al. (2009). The program's activities are guided by learning goals consistent with the Framework for K-12 Science Education and the Next Generation Science Standards (National Research Council, 2012; NGSS Lead States, 2013). Participants examine scientific phenomena as they deepen their understanding of crosscutting concepts, disciplinary core ideas, and science and engineering practices. The enacted STEM curriculum during this study had an overarching sustainability and ecojustice theme allowing students to learn about the impacts of pollution, water quality and availability, recycling and composting, green energy, climate change, and organic gardening. Students also engaged in engineering activities facilitated by university groups such as the National Society of Black Engineers (NSBE) as well as doctoral students in Human Centered Computing (HCC) who introduced students to robotics and how to code commands. Our participants attended weekly field trips that ranged from visiting informal science institutions such as the zoo, planetarium, and fisheries to research laboratories at the local university. 
Field trips in their formal schools are usually infrequent and the focus are oftentimes recreational rather than educational. All field trips in I AM STEM were carefully selected to complement the program's curriculum. The daily schedule varied, but generally, academics occurred in the mornings and extracurricular activities in the afternoons. Each morning, the participants were provided with a warm breakfast and engaged in affirmations about their brilliance and belongingness in STEM. These affirmations and songs were created by I AM STEM teachers, students, and the executive director. I AM STEM is neither an intervention nor remediation program, but rather emphasizes problem-based and experiential learning that exposes students to reading, mathematics, science, and social studies standards for the upcoming school year. Prior to the start of camp, there was a multi-day training for instructors (which consisted of certified teachers and staff), where they collaborated to design the curriculum highlighting standards that students oftentimes struggled with during the formal school year. In addition, students were given a pre-assessment on the first day of camp to determine their level of mastery across content areas so that teachers could provide personalized instruction to the participants. Teachers were trained by the executive director and a curriculum specialist to present concepts in non-threatening and culturally-relevant ways. In the afternoons, participants engaged in activities such as cooking, crocheting, ballroom dancing, financial literacy, Spanish, Black history brain bowl, team sports, swimming lessons, tennis lessons, engineering design challenges, and technology-focused activities where they created stop motion videos and public service announcements. The extracurricular activities were selected based on the strengths and skillsets of the teachers and staff.

I AM STEM 2015 lasted 25 days during the summer for 6 hours each day. The children were organized according to grade level - kindergarten and first grade; second and third grade; fourth and fifth grade; middle school; and high school. A total of 73 students participated, 39 of whom were girls and 34 were boys. All 73 participants identified as Black or biracial, and approximately $74 \%$ of the participants qualified for free or reduced lunch (Table 1).

Table 1. Demographics of I AM STEM Participants

\begin{tabular}{|c|c|c|c|c|}
\hline Grade Levels & Number of Students & Sex & Race & Free/Reduced Lunch \\
\hline Kindergarten-Grade 1 & 15 & $\begin{array}{l}\text { Boys: } 9 \\
\text { Girls: } 6\end{array}$ & $\begin{array}{l}\text { Black: } 13 \\
\text { Biracial: } 2\end{array}$ & $\begin{array}{l}(11 / 15) \\
73.3 \%\end{array}$ \\
\hline Grades 2-3 & 23 & $\begin{array}{l}\text { Boys: } 10 \\
\text { Girls: } 13\end{array}$ & $\begin{array}{l}\text { Black: } 20 \\
\text { Biracial: } 3\end{array}$ & $\begin{array}{l}(19 / 23) \\
82.6 \%\end{array}$ \\
\hline Grades 4-5 & 11 & $\begin{array}{l}\text { Boys: } 5 \\
\text { Girls: } 6\end{array}$ & $\begin{array}{l}\text { Black: } 10 \\
\text { Biracial:1 }\end{array}$ & $\begin{array}{l}(6 / 11) \\
54.5 \%\end{array}$ \\
\hline Middle School (Grades 6-8) & 13 & $\begin{array}{l}\text { Boys: } 6 \\
\text { Girls: } 7\end{array}$ & $\begin{array}{l}\text { Black: } 12 \\
\text { Biracial:1 }\end{array}$ & $\begin{array}{l}(10 / 13) \\
76.9 \%\end{array}$ \\
\hline High School (Grades 9-12) & 11 & $\begin{array}{l}\text { Boys: } 4 \\
\text { Girls: } 7\end{array}$ & Black: 11 & $\begin{array}{l}(8 / 11) \\
72.7 \%\end{array}$ \\
\hline TOTAL & 73 & $\begin{array}{l}\text { Boys: } 34 \\
\text { Girls: } 39\end{array}$ & $\begin{array}{l}\text { Black: } 66 \\
\text { Biracial: } 7\end{array}$ & $\begin{array}{l}(54 / 73) \\
73.9 \%\end{array}$ \\
\hline
\end{tabular}

In this study, the researchers focused on the STEM learning experiences of the fourth through eighth grade girls. These grade levels were selected because research suggests that Black girls begin losing interest in science and mathematics by middle school (Aud et al., 2010; Hanson, 2009; Mesa, Pringle, \& King, 2014). Twenty-four $4^{\text {th }}$ through $8^{\text {th }}$ grade students participated in I AM STEM. Of the 
24, 13 were girls (eight of whom qualified for free or reduced lunch), and the racial-ethnic composition of all 13 was Black/African American. Six girls were selected to participate in the study through the use of purposive sampling. A maximal variation strategy was employed to select a range of representative cases across experiences to delve deeply into the selected sample rather than surface-level analysis of all participants (Flick, 2009; Patton, 2002). The six criteria were (1) grade level, (2) type of school the participants attended, (3) number of years involved in I AM STEM , (4) household structure, (5) SES (as measured by free or reduced lunch status), and (6) if the participant received a sponsorship of any kind to attend I AM STEM . The names presented in Table 2 are all pseudonyms.

Table 2. Description of Research Participants

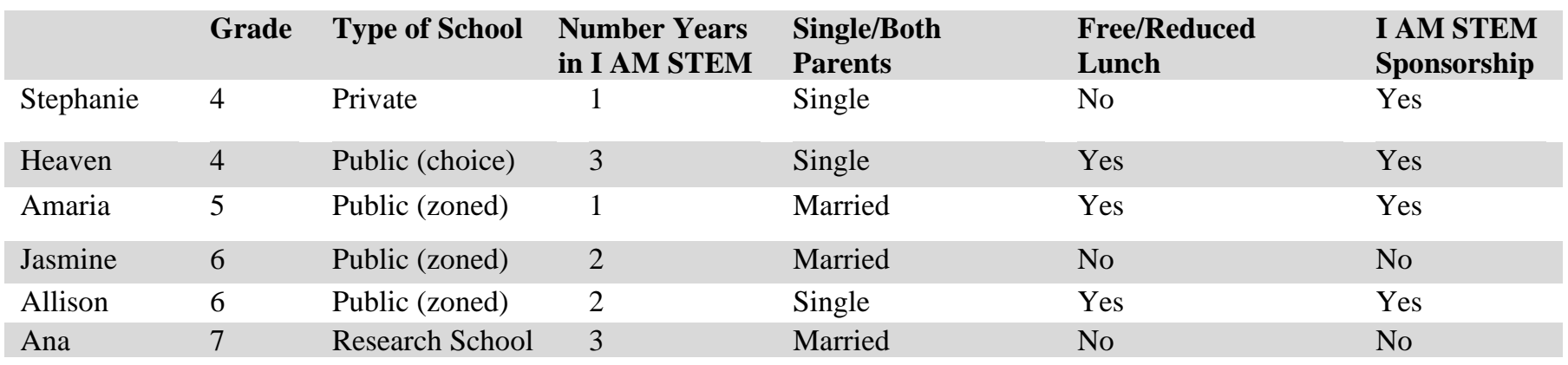

\section{Data Collection and Analysis}

This study occurred in two phases in which both data collection and analyses were continuously intertwined. The first phase took place during the summer of 2015 as the participants were immersed in I AM STEM. The data sources included participant observational field notes, researcher memos, student reflection journals, and samples of student work (Corbin \& Strauss, 2014). The researchers, as participant observers, were engaged as photographers and chaperones for the STEM activities and field trips. The researchers also wrote reflective summaries after each observation, and collected and analyzed samples of student work in the form of science journal entries, blog entries, and worksheets. It is important to note that the data sources from the first phase informed the second phase of data collection and analyses - individual interviews. Three retrospective individual interviews were conducted with each participant over a six-month period during the 2015-2016 school year immediately following the summer program. Multiple data sources from phase 1 informed the individual interviews, which allowed the girls to provide verbal accounts of their STEM learning experiences (Erickson, 2012; Westbrook, 1994). These verbal accounts with the researchers are the basis of the co-constructed counterstories.

A semi-structured interview protocol (included in Supporting Information) was used for each interview followed by an unstructured photo elicitation interview (Flick, 2009; Tinkler, 2013). The interview protocol consisted of five questions eliciting how the girls accessed, engaged in, and responded to, the STEM learning experiences in I AM STEM; how this learning was translated into practice; and the perceived impact of race, class, and gender on their STEM learning experiences (if any at all). Immediately following the semi-structured interview, the researchers selected photos and samples of students' work to further the conversation of ideas that were shared to provide deeper insights into how they constructed themselves as learners. For example, if a participant talked about the field trip to the fisheries during the semi-structured interview, the researchers presented a photo of the participant at the fisheries and a copy of her blog entry about that experience so that she could further develop the story. Each interview lasted approximately 60 minutes and was held at the community center. 
A profile was constructed based on the participants' responses during the first interview (which were informed by the observational field notes, researcher memos, and samples of their work). Seidman (2013) states that "crafting a profile or a vignette of a participant's experience is an effective way of sharing interview data and opening up one's interview material to analysis and interpretation" (p. 122). In crafting the first draft of the profile, we transcribed the first interview word-for-word with the coughs, sneezes, giggles, pauses, and idiosyncrasies. We kept the original transcript, but started a new document where we deleted all of the interview questions from the transcript so that only the girls' words remained in the document. We then selected passages of interest from the transcript which started the development of each girl's profile. We defined passages of interest as statements that assisted us in answering our research questions or passages that were essential in building the girls' profiles about their identities and lived experiences. Criteria for marking passages revolved around how the participants described themselves as STEM learners, their experiences in the informal STEM program and formal classes, and perceptions regarding the role of race, class, and gender on their STEM learning. We used a word processing program and copied and pasted all of the passages of interest for each participant into her own running document as a single transcript and read even closer to select the most compelling pieces to start crafting the counterstories.

Two successive interviews were conducted to clarify our interpretations of each girl's experiences, gain deeper understandings, and member check to ensure that the narrative being written accurately depicted the girls' perceptions and experiences (Creswell \& Miller, 2000; Morse, Barrett, Mayan, Olson, \& Spiers, 2008). Semi-structured interviews provided consistency about the general concepts that were covered during each interview (Corbin \& Strauss, 2014), and photo elicitation interviews encouraged storytelling and facilitated dialogue between the participants and researchers.

The researchers selected passages of interest from the interview transcripts to first craft a profile, then draft a narrative sketch, and finally construct the counterstory (King, 2016). During the process of co-constructing the counterstories, the researchers were guided by the research questions and worked with the girls to move the transcripts and journal entries into meaningful stories that had a logical development and flow. Seidman's (2013) techniques for crafting a profile served as a framework to construct the final counterstories. A detailed table of this process is included in Supporting Information.

Using narrative inquiry (Riessman, 2008), the six participants generated accounts of their informal and formal STEM learning experiences, and the perceived impact of race, gender, and class. Riessman (2005) stated that narratives refract rather than mirror the past, because storytellers interpret their experiences, not reproduce them. Therefore, the girls' representations and explanations of their STEM learning experiences were investigated by studying their personal and oral accounts collected in the data sources identified above. Riessman's (2005) typologies of interactional analysis and thematic analysis were therefore employed for data analysis. Interactional analysis views storytelling as a coconstructive process where the researcher and teller collaborate to create meaning (Riessman, 2005). This form of analysis occurred over a 6-month period during the three rounds of individual interviews leading to the construction of the counterstories. Through dialogue and member checking, the girls unpacked their STEM learning experiences in I AM STEM and their formal schools. After all counterstories were constructed, the researchers conducted close readings and identified emerging themes in response to the research questions (Riessman, 2005). We identified passages of text in the counterstories that were linked by common themes or ideas and created nodes in NVIVO (Charmaz, 2014). These nodes were then assigned into categories; three themes emerged from the data to answer our research questions and are presented below.

\section{Findings}


In this study, the voices of Black girls who participated in a community-based informal STEM program were elicited and their successes and challenges documented as they co-constructed their learning experiences. In our goal to understand the STEM learning experiences of the Black girls in both informal and formal contexts, we challenged the traditional methodology in which the words and acts of the research participants are reduced to statistical equations (Taylor, Bogdan, \& DeVault, 2015). The Black girls, as participants in the research, were elevated to the position of co-researchers and knowledge generators through the co-construction of their counterstories. While each story was personal and unique, collectively, they provided insights into issues of STEM learning for Black girls. Notably, the girls named their realities resulting in a deeper understanding and unearthing of new possibilities of STEM learning. The following themes emerged during data analysis: (1) Field trips and engagement with authentic science phenomena offered in I AM STEM ignited the girls' interests in STEM; (2) Black girls became agentic in continuing their engagement in STEM activities throughout the school year; and (3) Black girls perceived race to have the greatest influence on their formal STEM learning experiences. These findings depict a rich tapestry of the girls' experiences and are presented below supported by excerpts from their counterstories.

Field trips and engagement with science phenomena offered in I AM STEM ignited the girls' interests in STEM. The girls reflected on their STEM learning experiences in the communitybased informal STEM program, and discussed field trips as a major motivator to engage in STEM learning because they were afforded opportunities to visit novel places and learn more about their communities. In the informal learning environment, the participants went on field trips and were engaged in learning activities designed to foster civic responsibility and scientific literacy. The enacted lessons activities included issues of sustainability while also supporting their learning. As Jasmine described:

At the transfer facility, I learned that sometimes they take TV's that have like toxic chemicals in them. They recycle things like TV's, glass, stoves, and paint cans. I learned that they have different sections for the trash like they have the recycled stations and things that are not supposed to be in the trash. (Jasmine, 6th Grade)

Many of the participants reflected on the STEM learning experiences that included doing scientific investigations or visiting institutions like the Invention Museum. The activities exposed students to scientific phenomena and encouraged them to look for patterns and develop claims in response to scientific questions being investigated. For example, in physical science lessons, the participants examined phase changes and ultraviolet radiation and made meaningful connections to their lived experiences. In their reflections on formal science learning, the girls noted that they rarely had opportunities to go on field trips and be immersed in these types of STEM learning experiences.

I AM STEM is different from my school because we go on trips like 2 days per week. We don't do that at school. We would probably go on two trips the whole year in school. I wish we could have more freedom in school like we do in I AM STEM. (Ana, $7^{\text {th }}$ Grade)

I feel happy when I'm in science. My feelings for science is that it's a really cool thing to learn. I like when we can do experiments like chemical reactions or physical change. I would say that I AM STEM is better than school because we have more experiments in I AM STEM, and everybody listens and learns and has a great time. (Jasmine, $6^{\text {th }}$ Grade) 
During I AM STEM, participants visited the Wetland and Aquatic Research Center where they learned about freshwater resources, endangered species of sturgeon, and toured the aquaculture facility. Biologists taught the participants how to use dichotomous keys to identify aquatic invertebrates, and exposed them to water chemistry where they conducted tests using a water quality meters, hach kits, and secchi disks. Participants caught fish at the aquatic center and returned them to the water once they identified the species. They observed ponds filled with aquatic invasive plants, and learned about the importance of water to farming and the concept of aquacultures. In addition, participants were able to differentiate endangered and threatened species by examining four different species of sturgeon.

At I AM STEM, we also went to the fishery place. I took one of the bugs from out of the water and caught it with my hands. I learned that some bugs are not harmful. We asked a lot of questions about the bugs and we got to touch some of the fish in the tanks. I learned that some of the fish are fast and some of them you can't throw out into the wild because they can harm other fish. That day, I had caught a catfish. (Stephanie, $4^{\text {th }}$ Grade)

After we looked at the bugs, we went to the aquacultures. One of the fish in there had a funny looking mouth. There was another fish that had his eyes spread far apart. We saw another fish that looked like a shark. Then a big fish with a flat stomach, gills on the side, a flat mouth that went down like a sad face. Mrs. Sheila, the teacher at the fisheries, had showed us all different types of endangered fish... and then we went fishing. (Allison, $6^{\text {th }}$ Grade)

In addition to reflecting on the field trips, the girls shared in detail the experiments that they conducted, projects that they created, and problems for which they developed viable solutions. Students became motivated to participate in the learning experiences because they received opportunities to link new learning to existing knowledge, and this piqued their interests. In one of the activities, the participants were challenged to figure out how the Operation board game worked through a simulated activity using everyday materials. In Allison's reflections, she made a connection between the buzzer sounding in the activity to a surgeon who could be hurting a patient in surgery. Later stating her interest in pursuing a career in medicine she noted:

We also got to build a board game called Operation. First, we had to get a board, and then we got two wires and taped them. We had to find a square battery that worked, and tape it to the board, and then cut half of an empty toilet paper roll, and taped it to the middle of the board. Then we connected the wire to it, and put a light on the side. We put rice in the middle of the little hole. And then, if you touched the sides of the toilet paper roll, then the light lit up and made a beeping noise. This meant that you're hurting the patient, when you hear the beeping noise. (Allison, $6^{\text {th }}$ Grade)

The girls used technology such as iPads and heat temperature guns to engage with the natural world and learn about sustainability. They walked around the campus of the museum of natural history and gathered ideas on how to create a sustainable environment. In this activity, the girls blogged about how they could improve their neighborhoods and communities by making more sustainable decisions. They also observed and took photos of organisms in the local environment. These images were uploaded to the iNaturalist app that generated possible species based on the photo and location. The girls shared their observations, discussed with their peers and negotiated as they confirmed their findings. Experts at the museum also supported them in their identification of the organisms. The girls connected with a 
greater scientific community of other app users, and uploaded their photos and observations as they learned about biodiversity and their surrounding natural and physical environment. Furthermore, they created their own public service announcements (PSAs) about topics such as recycling, protecting earth's biodiversity, sources of water pollution, and other sustainability issues explaining the importance of protecting the plants and animals that they identified. These PSAs were then presented to the local community, their peers, and family members. In reflecting on this experience the girls noted:

We learned how to do something called blogs when we went to the university, and we had iPads. We got to do different things on it like go outside and explore, take pictures, and blog about it. I liked using the iNaturalist app where we took pictures of plants and insects to find out information about it. I don't really get to do that stuff in school. (Allison, $6^{\text {th }}$ Grade)

My favorite part about I AM STEM is when we got to go to the technology place at the university because we got to learn how to do a blog, and we got to go outside in nature and see other things like plants and bugs and alligators and stuff like that. It was fun! I also learned how to stand in front of a crowd and say things, like when I talked about some of the things I learned during the I AM STEM Graduation. We learned how to do everything in I AM STEM! (Stephanie, $4^{\text {th }}$ Grade)

Stephanie mentioned the effectiveness of incorporating technology by using the iNaturalist app and iPad to document her observations of various plants and insects, and how she gained confidence to present her knowledge to the general public. The girls engaged in an online platform where they shared photos and blogged about their interactions with organisms at the museum. Stephanie developed her communication and public speaking skills which was evident in her presentation during the culminating ceremony where the participants showcased their projects and newly developed skills to community members, family, friends, and sponsors. Stephanie's reflection emphasizes the impact of field trips and rich learning experiences that occur outside of the formal classroom. These experiential learning opportunities provide a platform for students to meaningfully engage in STEM, develop a deep understanding of scientific concepts, and effectively communicate their knowledge.

\section{Black girls became agentic in continuing their engagement in STEM activities throughout} the school year. The community-based informal STEM program provided opportunities for the girls to engage in STEM learning experiences outside of the classroom. After participating in I AM STEM, the girls actively continued their STEM engagement throughout the school year by joining clubs in their schools, revisiting some of the scientific institutions that they went to during the summer, and registering for other STEM camps. Participants were exposed to places in the community such as the Invention Museum, recycling facility, water reclamation plants, and solid waste management bureaus through field trips. Their familiarity with these institutions allowed them to become agentic in that they registered for classes offered at the Invention Museum, participated in spring break camps sponsored by the utility company, and joined science, robotics, and recycling clubs in their schools. To understand the magnitude of how the participants continued to engage in STEM learning post their participation in I AM STEM, we share Jasmine's experience of attending a spring break camp sponsored by the local utility company - emPower Camp. The purpose of emPower Camp was to expose local middle school students to diverse careers within the utility industry while introducing them to the fields of conservation, energy supply, energy delivery, natural gas, water/wastewater, and telecommunications as 
they toured the facilities and interacted with industry experts. This one-week program was free of charge and designed to train students with $21^{\text {st }}$ century skills needed to work in this industry.

For spring break, I decided to do a 1-week camp at emPower Camp with the utility company. They taught us how to check important factors in a house like the air conditioner, filters, and how to save energy. For example, if you change your filters and don't let them get dirty, that will help the AC to run better. We practiced on a vacant house and checked the water meter, the electrical meter, and different things in the house. (Jasmine, 6th Grade)

Jasmine chose to spend her spring break delving deeper into sustainability issues that were discussed in I AM STEM. Her immersion in this high-quality STEM experience allowed her to develop knowledge and skills that were not only relevant, but also applicable to her everyday life. Jasmine conducted an energy audit of her grandmother's home, and informed her grandmother about the need for more energyefficient doors and to increase the water pressure in her sinks. A motivating factor about Jasmine's experience at emPower Camp was her ability to look official by earning sticker badges for each skill that she mastered that she could affix to her vest.

What I liked most was that we got to wear this bright yellow vest to make us look like employees. I mean we looked official! We got stickers at the end of each day for each of the skills that we learned that we could put on our vest. It made me look like Dora the Explorer. I liked that we got free food, and at the end of each day we got free time to play games and talk to our friends. It was fun! (Jasmine, $6^{\text {th }}$ Grade)

The emPower Camp demystified processes such as how water is purified, how energy is delivered, and even how to conserve energy. Jasmine's involvement in the emPower Camp allowed her to identify with STEM in a meaningful way by seeing the real-world outcomes of her actions and connecting on a personal level. Jasmine was able to learn from industry experts and immediately applied those skills to her everyday life. After I AM STEM, Jasmine continued developing new skills such as learning how to read residential water pressure gauges and how to sort recyclable materials. Jasmine became agentic in continuing her STEM learning and participated in activities that encouraged her to both think and act!

The girls' sustained interest to continue their STEM learning was also evident in their involvement in school-based clubs. Amaria, a $5^{\text {th }}$ grade student, was exposed to robotics and engineering in I AM STEM where she learned the fundamentals of computer programming and how to operate robots. This was done in partnership with faculty and graduate students in Computer and Information Science and Engineering from a local Research I institution. The following school year, Amaria joined the robotics club at her school where she further developed her skills in the engineering design process. During I AM STEM, Amaria and her group were presented with real-world engineering challenges to design solutions for a robot to respond to commands. In collaboration with her team, she made sense of the problem, persevered in arriving at a solution, and was excited about competing against other teams' creations.

I am doing some of the STEM things that I did in I AM STEM in school now. So, we use STEM in robotics, 'cause we engineer, like we build things with like connector pins, batteries, and mess with all that kind of stuff. And we use axles, shafts, and axle-shafts. We also use mathematics 'cause we have to do the math to see how our robot's going to react. Like my robot, when we first tried to drive, it didn't connect with the controller, so we had 
to deconstruct it, and we had to construct it again, and we tried it again and it worked. (Amaria, $5^{\text {th }}$ grade)

Although research indicates that girls prefer a more collaborative rather than competitive environment (Crowe, 2003; Niederle \& Vesterlund, 2010), Amaria was motivated by the robotics competitions and possibility of making it to the championship rounds. Amaria's competitive nature ignited her interest in joining the Lego robotics club, but her exposure to these concepts in I AM STEM elevated her confidence to construct a robot that had the potential to qualify for the final rounds.

Mr. Owens is my robotics teacher at school, and he had taught us a lot of stuff since the first day. I got interested in robotics when he talked about the championship, like when they battle, that's when I got interested. 'Cause I'm very competitive and I told my friends, "I'm very competitive so if you guys don't get those robots by the last week before the competition, I'm out." That's what I told them because I wanted my robot finished. I wanted to build a whole clawbot. First we built the auto-pilot bot, and then we built the clawbot, and it's even harder than the auto-pilot bot...it's horrible! This is like the first year we've done robotics, so I AM STEM gave me an idea of what robotics was all about and how to build things. (Amaria, $5^{\text {th }}$ grade)

Amaria not only shared how the summer STEM learning experiences exposed her to the fundamentals of Lego robotics, but also how the ways in which she was challenged to think critically translated into her overall school performance. Amaria developed a passion for Lego robotics through her experiences at I AM STEM and her formal school that stimulated a possible interest in pursuing it as a career choice. She further adds

I have changed since I AM STEM just feeling a little smarter. In school, we started practice tests for the big state test, and I have gotten better grades. My school just gave awards and I got A/B Honor Roll. I was not an A/B student last year...I liked building a VEX IQ Clawbot. I want to continue with robotics because robotics is very fun and I think I can make a living out of it! (Amaria, $5^{\text {th }}$ grade)

Jasmine's involvement in emPower Camp, and Amaria's participation on the robotics team are two examples of how the girls became agentic in continuing their engagement in STEM learning after participation in I AM STEM. Early and deliberate exposure to the STEM disciplines has the potential to spark the interest of Black girls that may be sustained over time. Providing access to high-quality STEM programs within their communities allow Black girls to build foundational skills and confidence that can be further nurtured and developed in other outlets.

\section{Black girls perceived race to have the greatest influence on their STEM learning} experiences in schools. As the girls reflected on their formal STEM learning experiences, they shared the perceived impact of race, class, and gender on their STEM learning. All the girls identified their families as being middle-class. Three of the six participants qualified for Free and Reduced Lunch (FRL), which means they met the federal poverty guidelines based on their household size and family income. Regardless of their family's income, the girls did not comment deeply about their socioeconomic status (SES) or its perceived impact on their STEM learning. In fact, they felt privileged by their gender and class because they perceived girls to be more hardworking than boys and that their families had enough money to take care of their necessities. To understand how the girls made sense of 
their race, gender, and class, we share some of Ana's counterstory. In Ana's reflection about the perceived influence of class, she esteemed her parents highly for their financial decisions, and aspires to be like them when she grows up. Ana discussed the benefits of having both of her parents in the home, working together to provide for the family. Ana stated that she attends a good school and has access to quality teachers because her family makes decent money.

As for my class, I think my parents and my family make a good amount of money. We are not poor! The money that they make helps me because they can afford to get me into a better school to where I can have high success in life. They have to pay for a certain school to have the right kind of teachers to teach and not just give you a textbook and say "read this and then answer the questions". Good teachers have the whole class reading and working through the questions and help students follow through the questions to be able to answer hard questions. I'm the youngest, my older siblings think that they're getting treated unfairly because they say that I tend to get a lot more things than them. But us as our family...I love my family, like to death! They are my role models. I'm looking up to my family, basically. When I have kids, or whatever, I don't want to have a family that's not like my family. I don't want to be struggling, and I don't want to be in no money debt! (Ana, $7^{\text {th }}$ Grade)

In regards to gender, all of the participants responded enthusiastically about being girls and thought it positively influenced their STEM learning experiences. Ana extended the conversation and explained how the gender of the teacher played an important role in the educational experiences that she was afforded. In discussing the gender of her teachers she noted that even though she enjoyed being a girl, Mr. Wilson, her social studies teacher, showed favoritism to the boys in the class. On the other hand, she felt it was beneficial being a girl in science class, because her science teacher, Ms. Sullivan, showed preferential treatment to the girls. Ana explained:

I love being a female, I don't want to be a male. In science, Ms. Sullivan always says that females do much better than males. That saying has been going around our school for I don't know how long. One of the students said it in Mr. Wilson's Language Arts class the other day and you could tell that he got kind of offended. Ever since then, he has been showing more favoritism to the males in the class. That's why the girls have to be careful because if a female asks him for help, he'll say you should have been listening because females are better, remember? If the teacher is a male, he shows more favoritism to the males in the class because he wants the males to be successful. (Ana, $7^{\text {th }}$ Grade)

Ana perceived her class and gender to privilege her formal science learning experiences, but expressed concerns of being discriminated against due to her race. Even though Ana performed well in science class, she shared stories of specific instances where she felt racialized by Ms. Sullivan.

Thinking about my race and gender, me being Black impacts me more as a science learner because Ms. Sullivan, she's a female. She treats Brittany, who is a female, better than me and I'm a female, so all three of us are females, but which student is getting treated better? The White one. So I don't think it has nothing to do with gender. (Ana, $7^{\text {th }}$ Grade)

Heaven, a fourth grade student, shared similar sentiments as Ana, and expressed that White students have an advantage in her science class because of the teacher's race. She also described how she 
experienced more racialization from her teachers compared to her White peers. Heaven also believes that all races are equal and with excitement expressed that her friends were of different races.

My teacher is a White color, and Patricia is a White color, and their color is the same so they communicate. They know about things that happened in the past, like slavery and things like that. I think that my teacher kind of looks at me differently, but not my friends. Because Patricia, she doesn't really care what color I am, because she even says that Blacks and Whites are equal. I also think that Blacks and Whites are equal, and I see many Blacks and Whites who are friends at my school. (Heaven, $4^{\text {th }}$ Grade)

Heaven and Ana both experienced differential treatment from their teachers in the formal science classroom, and attributed it to their race. Race, as one component of their identities, became a vehicle for discrimination in science where the girls often felt marginalized, excluded and disconnected. Heaven, as an elementary school student, and Ana, as a middle school student, expressed similar sentiments of White women teachers showing preferential treatment to White girls in science class. Ana and Heaven were able to develop authentic and trusting relationships with their peers regardless of race. Nevertheless, the teacher as an authoritative figure was instrumental in shaping the types of experiences that they were afforded in science class. This reifies the importance of having counterspaces where girls of color can have an outlet to escape perilous microaggressions that may occur in their formal schools, and develop trusting relationships with teachers in their community.

\section{Discussion}

In this research, we elicited the voices of Black girls who participated in a community-based informal STEM program- I AM STEM, to understand their STEM learning in informal and formal settings, and the ways in which they translated their informal learning experiences into practice post-participation in the program. The results highlight the importance of providing Black girls with meaningful STEM learning experiences within the context of their community. Additionally, with regard to I AM STEM being strategically positioned within the girls' community - race and socioeconomic challenges provided ease of access while broadening their participation in STEM learning. The girls valued the knowledge and skillsets gained as a result of their participation in I AM STEM, and actively sought out opportunities to continue their STEM learning after the program ended. Consistent with current beliefs about teaching and learning science, they were afforded with opportunities to engage in scientific phenomena in relevant ways with real world applications (NGSS Lead States, 2013; Settlage, Southerland, Smetana, \& Lottery-Perdue, 2017), while giving credence to their lived experiences. The girls were active participants in their STEM learning as evidenced by their engagement in the field trips and inquiry-based science investigations, which Martin, Mullis, Foy, and Stanco (2012) reported can foster positive interests in science and have the potential to also increase achievement.

These experiences in the community-based informal STEM program juxtaposed the traditional nature of their formal school experiences as evidenced by the opening quote in this paper. Research supports that this traditional way of science instruction is often dominated by scripted curriculum requirements, teachers lecturing and students reading the science textbook, completing worksheets, and writing notes (Logan \& Skamp, 2008; Marshall, Horton, Igo, \& Switzer, 2009; Speering \& Rennie, 1996). These traditional approaches have resulted in surface-level understandings of scientific phenomena because students are not engaged in meaningful ways (Banilower, Cohen, Pasley, \& Weiss, 2010). Over 50 years ago, Delaney (1967) asserted that while "the field trip is education's oldest teaching technique; it is also one of the least understood" (p. 474). Despite research supporting the 
educational value of field trips, teachers rarely include outdoor activities such as field trips in their curriculum (Orion, 1993). Consistent with the girls' accounts, and supported in the literature, field trips are beneficial to students when teachers include the learning experiences as steps toward higher cognitive learning (Falk \& Dierking, 1997; Folkomer, 1981; Orion, 1993; Vinci, 1969). In I AM STEM, the participants went on field trips that provided direct exposure to their natural and physical world, and provided opportunities to build networks with experts in the field and foster their sustained participation in STEM activities after the program.

Participants had access to more technology and advanced equipment in their formal schools than the community center. However, they were provided with opportunities to engage with state-of-the-art equipment through our industry and university partnerships. Participants learned $21^{\text {st }}$ century skills and real world applications of those skills through field trips during and after the program. One such example was Jasmine's positioning as an expert within her family as she assisted her grandmother with the low water pressure in her kitchen sink. Jasmine developed expertise through her interactions with our industry partners during emPower Camp. These experiences informed her decision-making and ability to support change in her home and community. Bell et al. (2017) referred to this phenomena as developing practice-linked identities for educational equity and social justice. I AM STEM is speciallydesigned to provide a learning environment that is inclusive, relevant, and impactful. The types of experiences that students are afforded in formal and informal learning spaces should be connected to their interests, lived experiences, and identities as learners. The skillsets must also have practical utility and fulfill a need or goal of the local community (National Research Council, 2012).

The girls' experiences in I AM STEM also sparked a sense of urgency and excitement that they sought out opportunities to continue their engagement in STEM learning beyond their science and mathematics classes in school. This was evidenced by their membership in science and engineering clubs and participation in STEM related camps. These findings align with research from Tan, Calabrese Barton, Kang, and O'Neill (2013) who reported that the ways in which girls craft an interest in science through their out of school figured worlds impacts when and how they participate within their science classrooms. Therefore, the girls' participation in STEM camps and clubs influence their positionality and the resources that they draw upon to author identities in science. These authored identities are a reflection of the nature of STEM opportunities afforded to them, and the connectedness between their in-school and out-of-school experiences (Calabrese Barton et al., 2013). While this particular study does not explore authored identities, the girls shared the role of their perceived identities across learning contexts, which were valued and legitimized in the counterspace.

In reflecting on factors that undermined their engagement in STEM learning, the girls identified instances of discrimination from their classroom teachers due to the color of their skin. These findings are consistent with Smith-Evans et al.' (2014) report that teachers' perceptions of Black girls often involve racial and gender stereotypes that undermine the girls' potential for success. This finding aligns with Sandra Hanson's (2009) premise that Black girls are aware of the biases and inequities in the educational system due to their race and gender, and perceive that the color of their skin has played the most critical role in their unequal footing in science. Research indicates that even though Black girls are interested in science, they often do not feel welcomed and experience racism and sexism in science classrooms (Malcom. Hall, \& Brown, 1976; Rayman \& Brett, 1995; Vining-Brown, 1994). The girls shared occurrences of discrimination in their science classrooms, and attributed those acts to teachers rather than their peers. In agreement with Pringle et al.'s (2012) findings, the girls' accounts support the notion that teachers do not always conceptualize Black girls as science and mathematics achievers and thus position them in negative ways. Futhermore, in alignment with critical race methodology, the girls' 
interpretations of their formal school experiences challenged the notion of race neutrality and meritocracy.

Addressing the racial disparities that Black girls experience in schools and the larger society have the potential to sustain their interest and participation in the STEM disciplines. Gaughan and Bozeman (2015) purport that race, ethnicity, and socioeconomic status impact the representation of minority groups in STEM disciplines and highlight the dire need to address those structures that are barriers to diversification. According to the National Coalition on Black Civic Participation (2014), gender and racial stereotyping have contributed to the low participation of Black women in STEM fields. Many Black girls and women have reported subtle forms of discrimination and feelings of isolation and exclusion, and feeling trapped in toxic environments. Studies have shown that when members of the dominant group interact with their counterparts, they often come from a position of power, privilege, and internalized superiority (Bonilla-Silva, 2006; Picca \& Feagin, 2007). Black girls in this study expressed these sentiments from many of their science teachers as early as elementary school. Unfortunately, the teachers' lack of awareness or denial of their behavior does not lessen the severity of its impact. In fact, their unawareness and denial makes it more likely that those behaviors will continue (Sensoy \& DiAngelo, 2012).

Critical race methodology embraces the premise that race is a social construct and emphasizes the need for transdisciplinary perspectives to understand how racism, classism, and sexism impact people of color (Solórzano and Yosso, 2002b). These sociocultural constructs exist across space and time, and are situated within the context of American society as a means to organize and structure the social world (Parsons \& Bayne, 2013). The field of science education is limited in the research that has been conducted prioritizing race and centering student voice to conceptualize the ways in which these dynamics interact in complex ways across contexts. In this study, the girls engaged in a self-discovery process of naming their truths and sharing their stories, thereby providing many insights into the oppressive nature of their learning experiences. Critical race methodology centralizes experiential knowledge and is committed to social justice of naming and confronting racialized oppressions (Solórzano and Yosso, 2002b). The findings that emerged from the girls' counterstories revealed the importance of designing learning settings that decrease opportunity gaps and highlight the strengths and contributions of Black girls

To debunk the capitalistic agenda to broaden the participation of STEM, and promote STEM for social justice, we have to use more critical methodologies to approach this work and cultivate spaces where students can connect their learning across contexts and engage in research, practice, and policy in tangible ways. These spaces are essential for Black girls to discuss and even confront racism and sexism or power structures that seek to impede their progress in STEM academic spaces (Martin, 2009). It is in these spaces where Black girls can develop critical consciousness early in their schooling process to establish a sense of belongingness within the STEM disciplines. This study advocates for such spaces on program development and implementation levels, as well as scholarship that may emerge from these programs. As science education researchers, we have a responsibility to become more intentional in prioritizing discussions of equity for all and portraying truths from the perspectives of our participants. These truths when highlighted should not only forge new research questions but also form the basis for transformative practices of educators in both formal and informal learning spaces. As researchers, we must also recognize and act on injustices, dismantle discriminatory cultures being perpetuated in education, and with attention to equity, introduce all groups of students to the world of STEM.

\section{Conclusions and Implications}


In this study, Black girls were provided with a counterspace to share personal stories of strength and struggle related to STEM learning in both informal and formal spaces. Stories that may have otherwise been suppressed or internalized now have the potential to inform and transform the master narrative about Black girls in science. Having a safe space with positive support systems for these rich stories to emerge supports the need for counterspaces. The girls made themselves vulnerable and disclosed sensitive information as they reflected on and made sense of their STEM learning experiences. This research in a community-based learning environment provided an outlet for the unique experiences of Black girls in science to come to the forefront. The use of counterstories offered an alternative, and less positivistic, research method to portray the dynamic and complex experiences of Black girls in school and more specifically in science (Solórzano and Yosso, 2002b). Counterstories as a research method opened up new possibilities for Black girls to construct new meanings about the impact of their multidimensional identities across contexts. This call to awaken the voices of Black girls to speak STEM casts light on the lives and challenges that they face as STEM learners-from their perspectives. This study also contributed to the literature on Black girls and the social identities and psychological processes associated with the simultaneous racialized and gendered experiences in STEM educational settings (Ireland et al., 2018). Furthermore, our research reimagined the conceptual lens, methodology, and methods used to explore and present the STEM learning experiences of Black girls with authenticity, thus answering a call to account for the dynamicism, complexity, and uniqueness of those experiences across learning contexts (Tefera, Powers, \& Fischman, 2018). The context of the community-based program is a unique aspect of the study that informed the ways in which the girls made sense of their formal STEM learning experiences.

The findings confirm that when credence and counterspaces are given to Black girls, they are poised to reveal their luster toward STEM learning, and add to the body of knowledge on how to bridge the informal and formal STEM learning environments for Black girls to promote a more comprehensive understanding of their experiences. The girls expressed a heightened awareness of how factors within their learning spaces and interrelationships across settings informed the ways in which they defined themselves as STEM learners. Their articulation of their lived experiences as science learners elevated our understanding of the subtle and implicit factors that resulted in their successes and marginalization as STEM learners. It is these articulations that can now inform our enactment of equitable STEM learning experiences. Furthermore, the activities in I AM STEM connected to the girls' experiences in their community and were valuable in constructing their perceived identities on micro and macro levels.

Illuminating the voices of Black girls not only informs research and practice about appropriate and relevant informal programs for children of color, but how best practices can be translated into formal science classrooms for richer and more inclusive science learning experiences. This knowledge has the potential to inform broadening participation efforts about the types of experiences that Black girls value in informal STEM programs and the effects that these programs can have on their formal education and everyday lives. Understanding the role of informal STEM programs as potential counterspaces for Black girls can begin to advance research and practice on possible solutions to effectively prepare Black girls to become Black women in STEM.

The findings extend our knowledge of how to create opportunities for Black girls to share their stories and how to support them in becoming successful STEM learners. Providing a platform for the girls to describe and reflect on their learning experiences can provide the necessary insights to better provide for their engagement in STEM. This study also answers a call to move the equity agenda forward in science education through transformative action, research, and practice (Bianchini, Akerson, Barton, Lee, \& Rodriguez 2012; Rodriguez, 2013). Furthermore, this research has the potential to stimulate conversations and new questions on how science educators can create safe spaces outside of 
the formal learning environment to introduce Black girls to the world of STEM and make meaningful connections between their formal and informal STEM learning experiences. Programs like I AM STEM make STEM learning accessible for more populations of students while allowing them to make viable connections to learning in schools, thus potentially broadening the participation in science and engineering. Out of school science experiences provide images of possibilities, stimulate students' interests in STEM, positively impact their academic achievement, and give greater exposure to career options in the STEM fields. Longitudinal studies are needed to examine the educational and career trajectory of Black girls with sustained participation in community-based informal STEM programs like I AM STEM. Future research should investigate the supports, resources, knowledge, and practices that are afforded in these spaces, and the ways in which those experiences shape Black girls' ongoing engagement in STEM.

\section{Implications for Practice - Advocacy, Community, and Time (A-C-T)}

Although attention to research and advancing scholarship is important in academia, careful consideration of the implications are paramount in challenging issues such as equity and social justice and elevating the voices of populations of learners who have traditionally been silenced or overlooked. As we discuss and present the implications for practice, we suggest a consideration of advocacy, community, and time.

Advocacy - I AM STEM began as a response to fulfill a community need and is now informing our research and scholarship. As critical researchers, we can no longer afford to remain bystanders and just report on the injustices that exist related to racial, gender, and socioeconomic disparities. We have a responsibility to use the knowledge to promote actions and address those injustices toward securing equity and social justice within science education. In this research, we listened to the stories and created spaces that amplified the voices of those who have traditionally been underrepresented. Their voices provided powerful insights, so it was not necessary for us to speak on their behalf, but rather provide a platform where their voices can resonate through our work. In reflecting on research, we must problematize emerging scholarship and use more critical lenses to explore complex issues. Guided by Penuel and Gallagher's (2017) work, we must also seek to create research-practice partnerships as longterm and mutually-beneficial collaborations between practitioners and researchers around a problem of practice.

Community - As a community of science educators, we are uniquely positioned to impact the development and enactment of equitable science learning experiences for all learners. If we are to level the playing field to help all children find their passions, expand their horizons, foster strong relationships, and master new skills, we will need to become members or demonstrate an understanding of their communities. Some educators may experience feelings of discomfort and vulnerability, but it is imperative that we unite as a science education community and translate our knowledge into effective practices. How then can this be achieved? Our findings point to the need for greater engagement in transformative work within our communities which includes opportunities for STEM learning and the prospect of directly impacting learning within formal schools (NRC, 2015).

Time - Change does not happen instantaneously. In fact, to adjust the trajectory of STEM learning among populations who have been underserved will require much time and commitment as we seek to develop a trusting relationship. Too often our work within communities of color end with the 
funding period or the conclusion of data collection. From our engagement in this community, the interactions with the girls, and this study's findings, we recommend having a plan in place to allow for sustainability. Therefore, we propose a willingness to invest the time needed for transformation and the enactment of strategies to maintain long-term partnerships.

Investment of our time and our commitment to advocacy and community efforts play a significant role in understanding the STEM learning experiences of children of color. Our engagement in community spaces allowed the girls to feel a sense of safety to share their stories and confront widely held conceptions regarding the capabilities of Black girls. Attention to their stories is necessary if our actions as science educators will lead to successfully broadening their representation in the STEM disciplines. 


\section{References}

American Psychological Association. (2010). Publication manual of the American Psychological Association (6th ed.). Washington, DC, US: American Psychological Association.

Ashford, S. N., Wilson, J. A., King, N. S., \& Nyachae, T. M. (2017). STEM SISTA Spaces. Emerging Issues and Trends in Education, 3.

Aud, S., Fox, M. A., \& Kewal Ramani, A. (2010). Status and trends in the education of racial and ethnic groups (NCES 2010-2015). Washington, DC: National Center for Education Statistics.

Banilower, E., Cohen, K., Pasley, J., \& Weiss, I. (2010). Effective science instruction: What does research tell us? Center on Instruction.

Banks, J. A., Au, K. H., Ball, A. F., Ball, A. F., Bell, P., Gordon, E. W., . . Zhou, M. (2007). Learning in and out of school in diverse environments. Lifelong, life-wide, life-deep. Seattle, WA: Center for Multicultural Education, University of Washington.

Barton, A. C. (2007). Science learning in urban settings. Handbook of research on science education, 319-343.

Basu, S. J., \& Barton, A. C. (2007). Developing a sustained interest in science among urban minority youth. Journal of Research in Science Teaching, 44(3), 466-489.

Bell, P., Van Horne, K., \& Cheng, B. H. (2017). Special issue: Designing learning environments for equitable disciplinary identification.

Bianchini, J. A., Akerson, V. L., Barton, A. C., Lee, O., \& Rodriguez, A. J. (Eds.). (2012). Moving the equity agenda forward: Equity research, practice, and policy in science education (Vol. 5). Springer Science \& Business Media.

Bonilla-Silva, E. (1999). The essential social fact of race. American Sociological Review, 64(6), 899906.

Bonilla-Silva, E. (2006). What is racism? The racialized social system framework. Race, work, and family in the lives of African Americans, 13-43.

Brickhouse, N. W., Lowery, P., \& Schultz, K. (2000). What kind of a girl does science? The construction of school science identities. Journal of Research in Science Teaching, 37, 441-458.

Brickhouse, N. W., \& Potter, J. T. (2001). Young women's scientific identity formation in an urban context. Journal of Research in Science Teaching, 38, 965-980.

Buck, G. A., Akerson, V. L., Quigley, C. F., \& Weiland, I. S. (2014). Exploring the Potential of Using Explicit Reflective Instruction through Contextualized and Decontextualized Approaches to Teach First-Grade African American Girls the Practices of Science. Electronic Journal of Science Education, 18(6).

Burr, V. (2015). Social constructionism. New York, NY: Routledge.

Calabrese Barton, A., Kang, H., Tan, E., O’Neill, T. B., Bautista-Guerra, J., \& Brecklin, C. (2013). Crafting a future in science: Tracing middle school girls' identity work over time and space. American Educational Research Journal, 50(1), 37-75.

Case, A. D., \& Hunter, C. D. (2012). Counterspaces: A unit of analysis for understanding the role of settings in marginalized individuals' adaptive responses to oppression. American Journal of Community Psychology, 50(1-2), 257-270.

Catsambis, S. (1995). Gender, race, ethnicity, and science education in the middle grades. Journal of Research in Science Teaching, 32(3), 243-257.

Charmaz, K. (2014). Constructing grounded theory. Sage.

Cooper, H. M. (2003). Summer learning loss: The problem and some solutions. ERIC Clearinghouse on Elementary and Early Childhood Education. 
Corbett, C., Hill, C., \& St Rose, A. (2008). Where the girls are: The facts about gender equity in education. Washington, DC: American Association of University Women Educational Foundation.

Corbin, J., \& Strauss, A. (2014). Basics of qualitative research: Techniques and procedures for developing grounded theory. Thousand Oaks, CA: Sage.

Crenshaw, K. W. \& Allen, W. R. (2014). Don't let the gender gap overshadow deeper racial and economic disparities. Chronicle of Higher Education, 61(9), B24-B25.

Creswell, J. W., \& Miller, D. L. (2000). Determining validity in qualitative inquiry. Theory into Practice, 39(3), 124-130.

Crotty, M. (1998). The foundations of social research: Meaning and perspective in the research process. Thousand Oaks, CA: Sage.

Crowe, M. (2003). Jump for the Sun II: Can a monthly program change girls' and women's attitudes about STEM? Journal of Women and Minorities in Science and Engineering, 9(3\&4).

Delaney, A. A. (1967). An experimental investigation of the effectiveness of the teacher's introduction in implementing a science field trip. Science Education, 51, 474-481.

Delgado, R. (1990). When a story is just a story: Does voice really matter? Virginia Law Review, 76(1), 95-111.

Dierking, L. D., Falk, J. H., Rennie, L., Anderson, D., \& Ellenbogen, K. (2003). Policy statement of the "informal science education" ad hoc committee. Journal of Research in Science Teaching, 40(2), $108-111$.

Erickson, F. (2012). Qualitative research methods for science education. In B. Fraser, K. Tobin, \& C. J. McRobbie (Eds.), Second international handbook of science education (pp. 1451-1469). Rotterdam, The Netherlands: Springer.

Evans-Winters, V. E. (2005). Teaching Black girls: Resiliency in urban classrooms (Vol. 279). Peter Lang.

Evans-Winters, V. E., \& Esposito, J. (2010). Other people's daughters: Critical race feminism and Black girls' education. The Journal of Educational Foundations, 24(1/2), 11.

Falk, J. H. (1999). Museums as institutions for personal learning. Daedalus, 128, 259-275.

Falk, J. H. (2001). Free-choice science learning: Framing the discussion. In J. H. Falk (Ed.), Free-choice science education: How we learn science outside of school (pp. 3-20). Williston, VT: Teachers College Press

Falk, J. H. (2005). Free-choice environmental learning: framing the discussion. Environmental Education Research, 11, 265-280.

Falk, J. H., \& Dierking, L. D. (1997). School field trips: assessing their long-term impact. Curator: The Museum Journal, 40, 211-218.

Falk, J. H., \& Dierking, L. D. (2002). Lessons without limit: How free-choice learning is transforming education. Lanham, MD: Rowman \& Littlefield.

Falk, J. H., Staus, N., Dierking, L. D., Penuel, W., Wyld, J., \& Bailey, D. (2016). Understanding youth STEM interest pathways within a single community: The Synergies project. International Journal of Science Education, Part B, 6(4), 369-384.

Feder, M. A., Shouse, A. W., Lewenstein, B., \& Bell, P. (Eds.). (2009). Learning science in informal environments: People, places, and pursuits. Washington, DC: National Academies Press.

Feinstein, N. W., \& Meshoulam, D. (2014). Science for what public? Addressing equity American science museums and science centers. Journal of Research in Science Teaching, 51(3), 368-394.

Ferreira, M. M., \& Patterson, C. M. (2011). Improving equity through a science enrichment program. Advancing Women in Leadership, 31(1). 
Flick, U. (2009). An introduction to qualitative research (4th ed.). Los Angeles, CA: Sage.

Folkomer, T. H. (1981). Comparison of three methods of teaching geology in junior high school. Journal of Geological Education, 29(2), 74-75.

Gaughan, M., \& Bozeman B. (2015) Daring to lead: Bringing full diversity to academic science and engineering. Issues in Science and Technology, 31(2), 27-31.

George, Y. S., Neale, D. S., Van Horne, V., \& Malcolm, S. M. (2001). In pursuit of a diverse science, technology, engineering, and mathematics workforce. Retrieved January 9, 2016 from American Association for the Advancement of Science website: http://ehrweb.aaas.org/mge/Reports/Report1/AGEP/AGEP_report. pdf.

Giroux, H. A. (1988). Literacy and the pedagogy of voice and political empowerment. Educational Theory, 38(1), 61-75.

Hanson, S. (2009). Swimming against the tide: African American girls and science education. Philadelphia, PA: Temple University Press.

Hernandez-Gantes, V., \& Fletcher, E. C., (2013). The need for integrated workforce development systems to broaden the participation of underrepresented students in STEM-related fields. In R. T. Palmer \& J. L. Wood (Eds.), Community colleges and STEM: Examining underrepresented racial and ethnic minorities. NY: Routledge.

Horsford, S. D. (2011). Learning in a burning house: Educational inequality, ideology, and (dis)integration. New York, NY: Teachers College Press.

Howard, T. C. (2001). Telling their side of the story: African-American students' perceptions of culturally relevant teaching. The Urban Review, 33(2), 131-149.

Howard-Hamilton, M. F. (2003). Theoretical frameworks for African American women. New Directions for Student Services, 2003(104), 19-27. doi: 10.1002/ss.104

Ireland, D. T., Freeman, K. E., Winston-Proctor, C. E., DeLaine, K. D., McDonald Lowe, S., \& Woodson, K. M. (2018). (Un)hidden figures: A synthesis of research examining the intersectional experiences of black women and girls in STEM education. Review of Research in Education, 42(1), 226-254.

Jones, L. S. (1997). Opening doors with informal science: Exposure and access for our underserved students. Science Education, 81(6), 663-677.Juárez, B. G., \& Hayes, C. (2010). Social justice is not spoken here: Considering the nexus of knowledge, power and the education of future teachers in the United States. Power and Education, 2(3), 233-252.

Juárez, B. G., \& Hayes, C. (2012). An endarkened learning and transformative education for freedom dreams: The education our children deserve. Journal of Educational Controversy, 6(1), 5.

King, N. S. (2016). Awakening and elevating the voices of African American girls: Counterstories of informal and formal STEM learning experiences. Unpublished doctoral dissertation.

King, N. S. (2017). When teachers get it right: Voices of black girls' informal STEM learning experiences. Journal of Multicultural Affairs, 2(1), 5.

Ladson-Billings, G. (2013). Lack of achievement or loss of opportunity. Closing the opportunity gap: What America must do to give every child an even chance, 11.

Ladson-Billings, G., \& Tate, W., IV (1995). Toward a critical race theory of education. Teachers College Record, 97(1), 47-68.

Lane, T. B. (2016). Research environments as counterspaces? Examining spaces that inhibit and support science identity development for Black students in STEM. Urban Education Research and Policy Annuals, 4(1). 
Lee, C. D. (2017). Integrating research on how people learn and learning across settings as a window of opportunity to address inequality in educational processes and outcomes. Review of Research in Education, 41(1), 88-111.

Logan, M., \& Skamp, K. (2008). Engaging students in science across the primary secondary interface: Listening to the students' voice. Research in science education, 38(4), 501-527.

Malcom, S. M., Hall, P. Q., \& Brown, J. W. (1976). The double bind: The price of being a minority woman in science (No. 76-R-3). Washington, D.C.: American Association for the Advancement of Science. Retrieved from http://web.mit.edu/cortiz/www/Diversity/1975-DoubleBind.pdf

Maríñez-Lora, A. M., \& Quintana, S. M. (2010). Summer Learning Loss. In Encyclopedia of CrossCultural School Psychology (pp. 962-963). Springer US.

Marshall, J. C., Horton, R., Igo, B. L., \& Switzer, D. M. (2009). K-12 science and mathematics teachers' beliefs about and use of inquiry in the classroom. International Journal of Science and Mathematics Education, 7, 575-596.

Martin, D. B. (2009). Researching race in mathematics education. Teachers College Record, 111(2), 295-338.

Martin, M. O., Mullis, I. V., Foy, P., \& Stanco, G. M. (2012). TIMSS 2011 International Results in Science. International Association for the Evaluation of Educational Achievement. Herengracht 487, Amsterdam, 1017 BT, The Netherlands.

McCreedy, D., \& Dierking, L. D. (2013). Cascading influences: Long-term impacts of informal STEM experiences for girls. Philadelphia, PA: Franklin Institute.

Meador, A. (2018). Examining Recruitment and Retention Factors for Minority STEM Majors Through a Stereotype Threat Lens. School Science and Mathematics, 118(1-2), 61-69.

Mensah, F. M. (2013). Theoretically and practically speaking, what is needed in diversity and equity in science teaching and learning?. Theory Into Practice, 52(1), 66-72.

Mesa, J. C., Pringle, R. M., \& King, N. (2014). Surfacing students' prior knowledge in middle school science classrooms: Exception or the Rule? Middle Grades Research Journal, 9(3), 61-72.

Morse, J. M., Barrett, M., Mayan, M., Olson, K., \& Spiers, J. (2008). Verification strategies for establishing reliability and validity in qualitative research. International Journal of Qualitative Methods, 1(2), 13-22.

Nasir, N. S., Snyder, C. R., Shah, N., \& Ross, K. M. (2012). Racial storylines and implications for learning. Human Development, 55(5-6), 285-301.

National Coalition on Black Civic Participation, Black Women's Roundtable (2014). Black women in the United States, 2014. Retrieved from https://www.washingtonpost.com/r/20102019/WashingtonPost/2014/03/27/National-Politics/Stories/2FinalBlackWomenintheUS2014.pdf

National Research Council. (2011). Successful K-12 STEM education: Identifying effective approaches in science, technology, engineering, and mathematics. National Academies Press.

National Research Council. (2012). A framework for K-12 science education: Practices, crosscutting concepts, and core ideas.

National Research Council. (2015). Identifying and supporting productive STEM programs in out-ofschool settings. Committee on Successful Out-of-School STEM Learning. Washington, DC: The National Academies Press.

National Science Foundation, National Center for Science and Engineering Statistics. (2017). Women, Minorities, and Persons with Disabilities in Science and Engineering: 2017. Special Report NSF 17-310. Arlington, VA. Available at www.nsf.gov/statistics/wmpd/.

NGSS Lead States. (2013). Next Generation Science Standards: For states, by states. Washington, DC: National Academies Press. Www.nextgenscience.org/nextgeneration-science-standards 
Niederle, M., \& Vesterlund, L. (2010). Explaining the gender gap in math test scores: The role of competition. The Journal of Economic Perspectives, 24(2), 129-144.

Ong, M., Smith, J. M., \& Ko, L. T. (2018). Counterspaces for women of color in STEM higher education: Marginal and central spaces for persistence and success. Journal of Research in Science Teaching, 55(2), 206-245.

Orion, N. (1993). A model for the development and implementation of field trips as an integral part of the science curriculum. School Science and Mathematics, 93, 325-331.

Pai, A., Benning, T., Woods, N., McGinnis, G., Chu, J., Netherton, J., \& Bauerle, C. (2010). The Effectiveness of a Case Study-Based First-Year Biology Class at a Black Women's College. Journal of College Science Teaching, 40(2), 32.

Parsons, E. C. (2008). Learning contexts, black cultural ethos, and the science achievement of African American students in an urban middle school. Journal of Research in Science Teaching, 45(6), 665-683.

Parsons, E. C. (2014). Unpacking and critically synthesizing the literature on race and ethnicity in science education. In N. G. Lederman \& S. K. Abell (Eds.), Handbook of research on science education (Vol. 2, pp. 167-186). New York, NY: Routledge.

Parsons, E. C., \& Bayne, G. U. (2013). Conceptualizations of Context in Science Education Research: Implications for Equity. In Moving the Equity Agenda Forward (pp. 153-172). Springer, Dordrecht.

Patton, M. Q. (2002). Qualitative Research and Evaluation Methods Newbury Park, CA: Sage Publications Inc.

Penuel, W. R., \& Gallagher, D. J. (2017). Creating Research Practice Partnerships in Education. Harvard Education Press. 8 Story Street First Floor, Cambridge, MA 02138.

Philip, T. M., \& Azevedo, F. S. (2017). Everyday science learning and equity: Mapping the contested terrain. Science Education, 101(4), 526-532.

Picca, L. H., \& Feagin, J. R. (2007). Two-faced racism: Whites in the backstage and frontstage. Sociology, Anthropology, and Social Work Faculty Publications. Paper 11.

Pinkard, N., Erete, S., Martin, C. K., \& McKinney de Royston, M. (2017). Digital Youth Divas: Exploring narrative-driven curriculum to spark middle school girls' interest in computational activities. Journal of the Learning Sciences, 26(3), 477-516.

Pringle, R. M., Brkich, K. M., Adams, T. L., West-Olatunii, C., \& Archer, Banks, D. A. (2012). Factors influencing elementary teachers' Positioning of African American girls as science and mathematics learners. School Science and Mathematics, 112(4), 217-229.

Rayman, P., \& Brett, B. (1995). Women science majors: What makes a difference in persistence after graduation? The Journal of Higher Education, 388-414.

Rennie, L. J. (2007). Learning science outside of school. Handbook of research on science education, 125-167.

Riessman, C. K. (2005). Narrative analysis. Thousand Oaks, CA: Sage.

Riessman, C. K. (2008). Narrative methods for the human sciences. Thousand Oaks, CA: Sage.

Rivera Maulucci, M. S., \& Mensah, F. M. (2015). Naming ourselves and others. Journal of Research in Science Teaching, 52(1), 1-5.

Rodriguez, A. J. (2013). Epilogue: Moving the equity agenda forward requires transformative action. In Moving the Equity Agenda Forward (pp. 355-363). Springer, Dordrecht.

Seidman, I. (2013). Interviewing as qualitative research: A guide for researchers in education and the social sciences. New York, NY: Teachers College Press. 
Sensoy, Ö., \& DiAngelo, R. (2012). Is everyone really equal? An introduction to key concepts in social justice education. New York, NY: Teachers College Press.

Settlage, J., Southerland, S. A., Smetana, L. K., \& Lottery-Perdue, P. S. (2017). Teaching science to every child: Using culture as a starting point. $3^{\text {rd }}$ Ed. New York, Rutledge.

Shujaa, M. J. (1994). Too much schooling, too little education: A paradox of black life in white societies. Trenton, NJ: Africa World Press.

Smith, M. R. (2016). Black pearls: Examining the science identity development of African American girls in a culturally relevant STEM counterspace (Doctoral dissertation, UCLA).

Smith-Evans, L., George, J., Graves, F. G., Kaufmann, L. S., \& Frohlich, L. (2014). Unlocking opportunity for African American girls: A call to action for educational equity. Washington, DC: National Women's Law Center. Retrieved March, 10, 2015.

Solórzano, D., Ceja, M., \& Yosso, T. (2000). Critical race theory, racial microaggressions, and campus racial climate: The experiences of African American college students. Journal of Negro Education, 60-73.

Solórzano, D. G., \& Villalpando, O. (1998). Critical race theory, marginality, and the experience of students of color in higher education. Sociology of education: Emerging perspectives, 21.

Solórzano, D. G., \& Yosso, T. J. (2002a). A critical race counterstory of race, racism, and affirmative action. Equity \&Excellence in Education, 35(2), 155-168.

Solórzano, D. G., \& Yosso, T. J. (2002b). Critical race methodology: Counter-storytelling as an analytical framework for education research. Qualitative inquiry, 8(1), 23-44.

Speering, W., \& Rennie, L. (1996). Students' perceptions about science: The impact of transition from primary to secondary school. Research in Science Education, 26(3), 283-298.

Steele, C. M. (1997). A threat in the air: How stereotypes shape intellectual identity and performance. American psychologist, 52(6), 613.

Strayhorn, T. L. (2012). College students' sense of belonging: A key to educational success for all students. New York, NY: Routledge.

Tal, T. (2012). Out-of-school: learning experiences, teaching and students' learning. In B. Fraser, K. Tobin, \& C. J. McRobbie (Eds.), Second international handbook of science education (pp. 11091122). Rotterdam, The Netherlands: Springer.

Tan, E., Calabrese Barton, A., Kang, H., \& O'Neill, T. (2013). Desiring a career in STEM-related fields: How middle school girls articulate and negotiate identities in-practice in science. Journal of Research in Science Teaching, 50(10), 1143-1179.

Taylor, S. J., Bogdan, R., \& DeVault, M. (2015). Introduction to qualitative research methods: A guidebook and resource. John Wiley \& Sons.

Tefera, A. A., Powers, J. M., \& Fischman, G. E. (2018). Intersectionality in education: A conceptual aspiration and research imperative.

Tinkler, P. (2013). Using photographs in social and historical research. Thousand Oaks, CA: Sage.

Traphagen, K., \& Traill, S. (2014). How cross-sector collaborations are advancing STEM learning. Los Altos, CA: Noyce Foundation.

Vinci, T. G. (1969). Educational Field Trips for Disadvantaged Pupils in Nonpublic Schools. Evaluation of ESEA Title I Projects in New York City 1968-69.

Vining-Brown, S. (1994). Minority women in science and engineering education (Final Report). Princeton, NJ: Educational Testing Service. 
Weinberg, D. (2014). Contemporary social constructionism: Key themes. Philadelphia, PA: Temple University Press.

West-Olatunji, C., Shure, L, Pringle, R., Adams, T., Lewis, D., \& Cholewa, B. (2010). Exploring how school counselors position low-income African American girls as mathematics and science learners, Professional School Counseling, 13(3), 184-195.

Westbrook, L. (1994). Qualitative research methods: A review of major stages, data analysis techniques, and quality controls. Library \& Information Science Research, 16(3), 241-254.

Wing, A. K. (1997). Critical race feminism: A reader. New York, NY: New York University Press.

Zamudio, M., Russell, C., Rios, F., \& Bridgeman, J. L. (2011). Critical race theory matters: Education and ideology. New York, NY: Routledge.

Zipatlas.com (2018). Zip code atlas, area code, city \& state profiles. Retrieved from www.zipatlas.com 